\title{
To perform fetal gender determination in the mare by ultrasound during early and advanced gestation
}

\author{
Anna Tönissen 1,2, Gunilla Martinsson², Henning Otzen', Katharina Schürmann², Saskia Schütze ${ }^{1,2}$, Franziska Ertmerl, Ana Kassens' \\ Jutta Sielhorst', Ralph Brehm ${ }^{3}$ and Harald Sieme \\ ${ }^{1}$ Clinic for Horses - Unit for Reproductive Medicine, University of Veterinary Medicine Hannover, Hannover, Germany \\ 2 National Stud Lower Saxony, Celle, Germany \\ ${ }^{3}$ Institute of Anatomy, University of Veterinary Medicine Hannover, Hannover, Germany
}

\begin{abstract}
Summary: This study aims to review current knowledge on equine fetal sexing with special reference to the authors field experience using the non-invasive transabdominal approach. Early gender determination performed transrectally by identifying the genital tubercle is specific with a small time frame; it is best performed from day 59 until 68. The examiner has to be experienced to scan the right planes for finding the genital tubercle in either sex. Advanced sex determination can be performed transrectally from 90 up to 140 days of gestation, afterwards reaching the fetus hindquarters transrectally is almost impossible and the transabdominal alternative has to be chosen. External genitalia and gonads have to be found and good knowledge of fetal anatomy is required. For more advanced gestation, the importance of representing the gonads and especially outlining their B-Mode echotexture and vascularisation by Doppler sonography increases. For the transrectal approach for gender determination, mares have to be calm and relaxed, so the use of sedation and smooth muscle relaxants might be necessary and the risk of perforating the rectum has to be taken into consideration. Transabdominal examination shows high acceptance in mares and bears a low risk, sedation is not necessary and movement of mare and fetus can be compensated easily by moving the ultrasound probe along the abdomen. Equine fetal sex determination is a tool in equine reproductive medicine which becomes more important and interesting for breeders in order to plan the mare s future breeding prospects. With enough time, patience, practice and good equipment it can be performed by practitioners easily as an additional service for clients. The method to be selected depends on the stage of gestation and on fetal presentation. If movements of the fetus prevent the accomplishment of sex determination, the examination should be repeated later. Advantages of gender determination during advanced gestation by transabdominal ultrasound other than economical reasons are the accomplishment of a check up on pregnancy and fetal well-being, great acceptance by the clients and a good way to perform gestation control in ponies and small horses, although this may take more time for preparation and examination.
\end{abstract}

Keywords: mare / fetal gender determination / transrectal ultrasonography / transabdominal sonography / reproduction

Citation: Tönissen A., Martinsson G., Otzen H., Schürmann K., Schütze S., Ertmer F., Kassens A., Sielhorst J., Brehm R., Sieme H. (2015) To perform fetal gender determination in the mare by ultrasound during early and advanced gestation. Pferdeheilkunde 31, 153-158

Correspondence: Prof. Harald Sieme, Clinic for Horses, Unit for Reproductive Medicine, University of Veterinary Medicine Hannover, Bünteweg 15, 30559 Hannover, Germany, E-mail: harald.sieme@tiho-hannover.de

\section{Introduction}

In horse breeding commercial interests become more important due to the difficult economical situation. The value of a pregnant mare can be set differently if the gender of the fetus is known. Decisions about the future of broodmares can be made based on the sex of the offspring (Bucca 2011). Knowing the possibility to identify its gender in advance, breeders are interested for different reasons and may use this technique for managing their stock (Holder 2011). During early and advanced gestation determination of the fetal sex can be performed properly.

Early gender diagnosis by transrectal ultrasonography is based on identification and location of the genital tubercle, between 54 and 84 days of gestation (Curran and Ginther 1989). The genital tubercle is a small bilobulated structure which is located ventrally between the hind legs. It can be identified as early as 52 or 53 days of gestation and is the precursor of the penis in male and of the clitoris in female fetus (Holder 2014). At that time the distance of the tubercle between tail and umbilical cord is equal, but beginning on day 55, it migrates in caudal direction, towards the tail in the female and in cranial direction towards the umbilical cord in the male fetus. The best results in fetal sexing can be achieved between day 59 and 68 (Bucca 2005). Until day 80 the examination can usually be performed, afterwards the amniotic fluid decreases, the uterus is pulled over the pelvic rim and the fetus sinks ventrally and is hardly accessible for imaging any longer (Holder 2011). Early fetal gender determination requires good equipment, a lot of practice and experience from the examiner in order to be performed in an acceptable timeframe to make a reliable predication about the sex of the fetus. Another disadvantage of early sex determination is the short period of time it can be performed, which is usually right in the middle of the breeding season and the evaluation of only one feature of the fetus.

Afterwards gender determination can be conducted beginning on day 90 up to day 260 . The examination of the mares after breeding season, throughout the year is possible, this is a great advantage for the breeder and usually for the examiner as well because of the lower workload after the season. Not only the window of time is wider, also the evaluable gender-specific differences increase. Several parameters of the fetal well-being can be gathered, such as movement and heart rate, aortic diameter and growth of the fetus (Bucca et al. 2005). Fetoplacental well-being can be evaluated as well, important parameters for that purpose are combined thikkness of uterus and placenta (CTUP), the echogenicity of fetal fluid and the presence of echogenic free floating particles (Reef et al. 1995). Late fetal sex determination is based on the identification of different distinctive features, in the male fetus 
penis, prepuce, scrotum and gonads, in the female fetus mammary glands including nipples, vulva, clitoris and the gonads can be visualized. Access can be gained to the regions of interest by transrectal (90-150 days) or transabdominal ultrasonography, or by a combination of both techniques depending on fetal presentation and movement.

\section{Method to perform gender determination during early gestation}

\section{Equipment and required data}

Soft examination gloves, lubricant, stocks to restrain the mare, real time portable ultrasound unit with linear probes that work at frequencies from 5 to $7,5 \mathrm{MHz}$ with video-tape function. The screen of the ultrasound unit has to be set at a level and distance that the examiner can take a close look and possibly change the settings. Quiet surroundings, lights adjusted for a good view on the screen should be provided and the date of the last mating has to be known. The rectum has to be emptied.

Tranquilizing the mare is usually not necessary. The common drugs used for sedation of horses are lipophilic, the placental barrier is passed and the fetus is affected. During sedation the vital parameters of the mare (heart rate, cardiac output, breathing frequency and volume) are decreased and the fetus has to deal with the lack of nourishment. None of the common sedative drugs are prohibited for mares until mid gestation, but because of the affection on the fetus they should be excluded. If the use is still necessary to calm the mare and keep the level of stress down, the lowest possible but effective dose should be chosen (Hubbell 2011). Tranquilizers relax the uterus what may cause a subsidence into the abdomen, which will enlarge the distance between the ultrasound transducer and the fetus and makes the gender determination more difficult. Most mares accept the examination as long as they are restrained in stocks and in quiet surroundings $(\mathrm{Ho} /$ der 2011 ).

\section{Technique}

The entire uterus should be scanned until fetal body-parts are seen. First orientation should be established, therefore good knowledge of fetal anatomy is indispensable. Landmarks, helping to set orientation about the position of the fetus, must be found. Fetal heart, skull and chest point out cranial direction, stomach (typical gastric-shaped, black) and tail point out caudal direction, the spinal cord with the rips coming off it to both sides points out dorsal and the umbilical cord points out ventral direction. After landmarks are found the presentation and position of the fetus should be determined properly. To establish a better view of the fetus, the distance to the transducer can be lowered by pushing it on to the uterus carefully or by turning it slightly to the left or right, until the view of the fetus, especially of the genital tubercle, is better. However, all kinds of manipulation on the uterus can cause drifts of the allantoic fluid which encourage the fetus to move. Movement causes acoustic shadows and the orientation has to be established again or the fetus may have to be found again if it vanished from the scanned area.
After orientation is established, the focus must be on the caudal fetal abdomen, which should be scanned in different planes (frontal, oblique and cross-sectional) to find the genital tubercle. In the male fetus a hyperechoic equal sign will appear ventro-median, caudal of the umbilical cord. By using a plane vertical to the fetal vertebrae there are three hyperechoic marks to be seen on the hindquarters, the first is the tail head and the other two are the tibias, which should form a triangle. In the female fetus, the tubercle appears ventral of the tail head. By using the described plane, the triangle will have another hyperechoic sign in the middle, associated to the tail head (Holder 2014). Male gender usually can be determined better and faster because the genital tubercle can be seen in more planes than in the female gender (Livini 2010). Attention has to be paid to artifacts, which easily can appear near the umbilical cord. If the examiner is not sure about the sex, a statement should not be made. To prevent the clients from loosing trust in early gender determination, no guessing should be made, but the examination should be repeated a few days later and at least a few hours later ( $\mathrm{Ho}$ der 2011 ). Other reasons for a wrong determination can be due to the inability to determine the orientation of the fetus or to scan its posterior third properly, so that the genital tubercle is not visible. Especially in females, the genital tubercle may not be detected because it is hidden by the tail head (Mari et al. 2002). Videotaping of the examination can clearly increase the quantity of positive determinations (Merkt et al. 1999). It is recommendable to take a close view of the genital tubercle and the surrounding area, especially the umbilical cord and tail head, at least three times to reach an adequate level of certainty and keep the errors down (Curran and Ginther 1991).

\section{Method to perform gender determination during advanced gestation}

\section{Transrectal approach}

Equipment and required data

Soft examination gloves, lubricant, stocks to restrain the mare, real time portable ultrasound unit with linear probes that work at frequencies from 5 to $7,5 \mathrm{MHz}$ with video-tape and Doppler function. The screen of the ultrasound unit has to be set at a level and distance that the examiner can take a close look and change the settings if necessary. Quiet surroundings and the lights adjusted for a good view on the screen should be arranged. The date of the last mating has to be know. The rectum should be emptied properly. Mares should only be tranquilized if it is really necessary.

\section{Technique}

Known from personal experience, the hindquarters of the fetus are reachable by transrectal examination from 90 until 140 days. If the fetus is in posterior presentation, the hindquarters can be explored adequately, in transverse presentation they may also be reachable. Afterwards, the hindquarters of the fetus are barely accessible and a proper view of the main area of interest is almost impossible, wherefore the transabdominal approach should be chosen. During this stage of gestation sex determination will be based on the external genitalia and the 
gonads. Once the fetal hindquarters are in view, diagnostic parameters have to be identified. In the male fetus, these are penis, scrotum, urethra and gonads. In the female one, mammary glands, nipples, vulva, clitoris and gonads are to be found. The gonads are equally shaped and located in both sexes, in the male fetus with a homogenous echogenicity and a typical hyperechogenic line along the longitudinal axis in the middle of the gonad. In the female gonads, the echogenicity is bizoned, because of the different structure of cortex and medulla. These features can be visualized even better by using color Doppler ultrasonography (see Fig. 1).

In the male fetus the penis appears as hyperechoic trilobulated structure. It may be mantled into the prepuce, after 5 months it is usually flaccid, in some cases an erected penis can be seen. Because of the close neighborhood to the umbilical cord it may reflect the pulsation of the umbilical vessels. The scrotal compartments can be visualized as two equally shaped hypoechogenic oval-shaped structures with diagonal orientation towards the perineal urethra. By using an oblique plane to see the hind limbs, the anogenital raphe may appear as a hyperechogenic slim structure between the limbs (Bucca 2011 , Curran and Ginther 1993). The circular or ellipsoidal shaped urethra is to be visualized perineally or running along the full length of the penis with cross-sectional or longitudinal scans.

\section{Transabdominal approach}

Equipment and required data

Stocks to restrain the mare and a real time portable ultrasound unit with a convex probe that works at frequencies from 2 to $6 \mathrm{MHz}$ that a scanning depth up to $25 \mathrm{~cm}$ is reachable with both a video tape and a color Doppler function. The screen has to be set on a level and distance that the examiner can take a closer look and change the settings anytime. Quiet surroundings, lights adjusted, mating date, and a good knowledge of fetal anatomy should be provided. Skin disinfectant containing alcohol, coupling gel and clipping machine should be kept handy. Clipping is usually not necessary, when the examination is performed during the summer or fall. Sedation of the mare is not necessary, although the decreasing fetal activities due to the tranquilization can cause the fetus to sink deeper into the uterus, which reduces the distance between probe and fetus and improves scanning quality. Still, there are effects on the vital parameters of the fetus and sedation should only be used if there isn 't any other way to examine the mare properly.

\section{Technique}

Alcoholic skin disinfectant should be brought on to the abdomen between udder and xyphoid with a sponge or be sprayed on, if the mare tolerates it. Keeping the mare calm and providing a quiet surrounding is as important as during early gestation, because the fetus may change position in case of excitement especially during the 5th and 6th month of gestation. Examination starts on the left side, examiners right shoulder is positioned close to the left flank, the probe is held with the right hand, viewing direction is up front to the mares head. Scanning starts in front of the udder and continues along the ventral abdomen until the fetus is seen and the hindquarters can be located. After 150 days, in most cases the fetus is found in anterior position wherefore fetal hindquarters appear in the mid abdomen; they move further cranial due to growth of the fetus. After 8 months of gestation, they are found in the cranial third of the abdomen near the xyphoid. If the fetus isn 't found on the left side or the hindquarters are harder to reach, the examiner changes to the right side of the mare. Landmarks for orientation such as beating heart, stomach and spinal cord should be established. The extending costal arch and the flexed pelvic rim can cause acoustic shadows. The elongation of the umbilical cord with loops may also impair the view. The umbilical cord can be distinguished from other fetal anatomical structures by 3 nonechogenic areas encircled by a wide echogenic line and the bloodflow.

Gender determination in advanced gestation is based on the identification of external genitalia and gonads, too. No structural changes occur in these organs from 150 days to term, the size on the other hand changes and as a consequence, their visibility varies. As gestation progresses, determination of external genitalia is getting more difficult because of fetal growth and acoustic shadows. After day 200 external genitalia can't be identified consistently at every examination (Renaudin et al. 1997). During advanced gestation gender determination is mainly focussed on scanning the fetal gonads. With increasing size their visualization is getting easier and their characteristic vascularisation can be shown well by Doppler-sonography. The fetal gonads extend within the fetal abdomen, and reach their ultimate weight $(50-70 \mathrm{~g})$ between month 6 and 7 because of hyperplasia of interstitial cells associated to the marrow (Hoffmann et al. 2009).

The penis with its hyperechoic glans penis can be found behind the umbilical cord. Male gonads are found in the ventrocaudal abdomen, ventral to the kidneys, dorsal to the fetal bladder. They are uniformly oval shaped and echoic structures with a homogenous texture equal to the fetal liver, with a length between 2 and $7 \mathrm{~cm}$ and a hyperechoic longitudinal line in its center, presenting the mediastinum testis. After 125 days the line may not be visible constantly. Using Doppler ultrasonography, an intense signal along the longitudinal axis, representingblood flow along the mediastinum testis, and a signal on the lateral contour representing the pampiniform plexus, will appear (Resende et al. 2014). From first hand experience it can bereported, that the vascularisation of the plexus can 't be seen in every fetus, in contrast to liquid flux in the mediastinum testis.

In the female fetus, mammary glands appear triangular or trapezoidal shaped and the nipples are visible as two hyperechoic areas on the cranial margin of the glands. By scanning the perineal region, the hyperechoic clitoris is detectable by its typical teardrop shape, the vulva can be seen between anus and clitoris. These anatomical structures can be found by investigating the pubic area, frontal and oblique planes bring the best scanning results.

Fetal gonads in females are equally shaped, sized and located as in the male, but a separation between the cortex and medulla of the ovary is detectable as a hyperechoic circle around the central echodense core, representing the cortico-medullary 
border. This pattern can be seen by Doppler ultrasonography as well, with a strong circular signal on the outer layer.

Doppler sonography is found to be an effective tool to determine fetal sex after 150 days. The accuracy is raised especially in the male sex, but attention has to be paid to artifacts, caused by vascularized tissue surrounding the gonads and by movement of the fetus. The examiner has to be experienced enough to recognize artifacts to perform proper sex determinations.
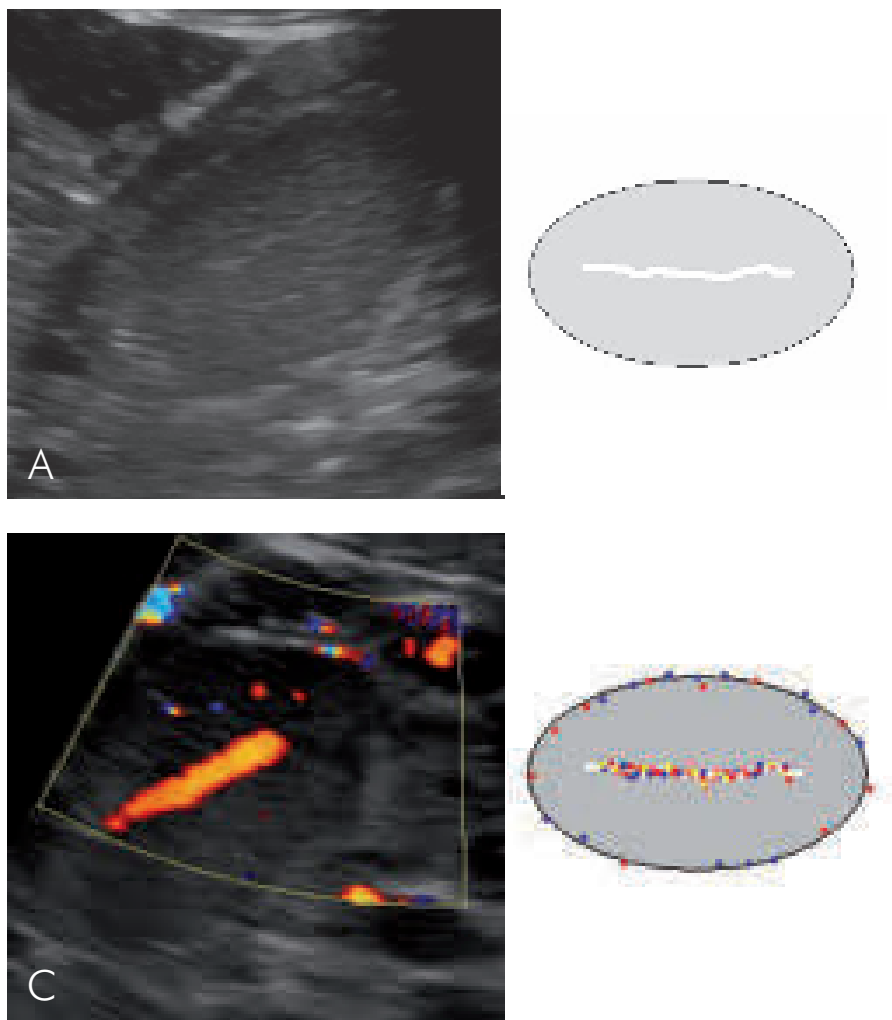

Fig. 1 Contour drawings and real B-Mode and Doppler-sonographic, transabdominal images of fetal gonads in male and female fetus obtained in mares by during advanced gestation. Examination was performed from the left side of the standing mare with a convex probe working at a frequency of $3.5-5 \mathrm{MHz}$ and scanning depth of approx. $16 \mathrm{~cm}$; sedation of the mare is normally not necessary. For good coupling alcoholic skin disinfectant was sponged on to the abdomen from the udder to the xyphoid. The probe was moved along the abdomen until the fetus becomes visible. The fetus will be found caudally, around and above the udder between 3 and 4 months of gestation, afterwards it changes in anterior position and can be found further cranially between udder and xyphoid. The best time to perform the transabdominal approach is from day of gestation d 120 to d240 (4th-8th month).

A) B-Mode sonogram of a fetal male gonad d219 with typical oval form and both an homogeneous echotexture and hyperechogenic line crossing along the longitudinal axis representing the mediastinum testis.

B) B-Mode sonogram of a fetal female gonad d 119 with typical oval form and a hyperechoic circle around the echodense center representing the border between cortex and medulla of the ovary.

C) Doppler-sonogram of a fetal male gonad d219 with typical oval shape and intense signal along the longitudinal axis, representing blood flow along the mediastinum testis and a signal on the lateral contour representing blood flow within the plexus pampiniformis.

D) Doppler-sonogram of a fetal female gonad d132 with typical oval shape and a strong circular signal representing the cortico-medullary border. Schemata sowie B-Mode- und Doppler-sonographische, transabdominale Aufnahmen fetaler Gonaden männlicher und weiblicher Pferdefeten bei fortgeschritten tragenden Stuten. Die Untersuchung in der fortgeschrittenen Gravidität erfolgt von der linken Körperseite an der stehenden Stute mit einer konvexen 3.5-5 MHz-Sonde mit einer Eindringtiefe von ca. $16 \mathrm{~cm}$; eine Sedation der Stute ist im Regelfall nicht notwendig. Für eine gute Ankoppelung wird das Abdomen vom Euter bis zum Xyphoid mit alkoholischem Hautdesinfektionsmittel benetzt. Die Sonde wird entlang des Abdomen geführt bis der Fetus sichtbar wird. Vom 3. bis 4. Monat befindet sich der Fetus caudal neben und über dem Euter, danach sinkt der Fetus ab liegt in Vorderendlage und ist cranial zwischen Euter und Xyphoid darstellbar. Der geeignete Zeitraum für die transabdominale Untersuchung beginnt ab dem 120. und reicht bis zum 240. Trächtigkeitstag (4.-8. Monat).

A) B-Mode Darstellung einer männlichen fetalen Gonade am 219. Trächtigkeitstag mit typischer ovaler Form und homogener Echotextur sowie einer - das Mediastinum testis repräsentierenden - hyperechogenen Linie entlang der longitudinalen Achse

B) B-Mode Darstellung einer weiblichen fetalen Gonade am 179. Trächtigkeitstag mit typischer ovaler Form und hyperechogener innerer Kreislinie um das echodichte Zentrum herum; die Kreislinie trennt die äußere Rinden-von der inneren Markschicht des Ovars.

C) Dopplersonographische Darstellung einer männlichen fetalen Gonade am 219. Trächtigkeitstag mit typischer ovaler Form und intensivem Dopplersignal entlang der longitudinalen Achse, welches Blutfluss entlang des Mediastinum testis repräsentiert. Das Dopplersignal an der lateralen Kontur stellt Blutfluß im Plexus pampiniformis dar.

D) Dopplersonographische Darstellung einer weiblichen fetalen Gonade am 132. Trächtigkeitstag mit typischer ovaler Form und intensivem zirkulärem Dopplersignal entlang der Grenze von äußerer Rinden- und innerer Markschicht. 
ultrasonography inflicted a lower stress reaction than the transrectal technique in non-lactating mares. The duration may be a little longer but with increasing experience, the right place and angle to see the gonads can be found quickly and there is no risk of perforating the mares rectum.

Not less than three of the described features should be determinated before a diagnosis is made: In the male fetus, external genitalia (penis with glans) and gonads with the hyperechogenic line along the longitudinal axis and the corresponding signal by Doppler ultrasonography should be seen, possibly also a signal on the lateral contour. In the female fetus, the external genitalia (mammary glands, clitoris, vulva) and gonads showing the typical bizoned structure and the intense circular signal by Doppler ultrasonography due to the cortico-medullary border, should be seen. The Examination takes between 2 and 15 minutes depending on the experience of the examiner and the cooperation of mare and fetus.

\section{Acknowledgements}

The "German Thoroughbred Breeding Association", the "Mehl-Mülhens Stiftung" and the "Stiftung Gestüt Fährhof" are acknowledged for their support.

\section{References}

Bucca S. (2005) Equine fetal gender determination from mid- to advanced pregnancy by ultrasound. Theriogenology 64, 568-571

Bucca S., Fogarty U., Collins A., Small V. (2005) Assessment of fetoplacental well-being in the mare from mid-gestation to term: transrectal and transabdominal features. Theriogenology 64, 542-557

Bucca S. (2011) Fetal gender determination from mid to advanced gestation. In: McKinnon AO.,Squires EL., Vaala WE., Varner D.D.(eds), Equine Reproduction 2nd Edition, Ames: Wiley-Blackwell; 2011:2094-2098

Curran S., Ginther O. J. (1989) Ultrasonic diagnosis of equine fetal sex by location of genital tubercle. J. Equine Vet. Sci. 9, 77-83

Curran S., Ginther O. J. (1991) Ultrasonic determination of fetal gender in horses and cattle under farm conditions. Theriogenology $36,809-814$

Curran S., Ginther O. J. (1993) Ultrasonic fetal gender diagnoses during month 5 to 11 in mares. Theriogenology 40, $1127-1135$

Hoffmann B., Leiser R., Schuler G. (2009) Physiologie und Anatomie der Trächtigkeit, Trächtigkeitsdiagnostik. In: Aurich, C., Reproduktionsmedizin beim Pferd 2. Auflage, Parey; Kapitel 8, 125-154

Holder R. D. (2011) Fetal sex determination in the mare between 55 and 150 days of gestation. In: McKinnon A. O., Squires E. L., Vaala W. E., Varner D. D. (eds.), Equine Reproduction 2nd Edition, Ames:Wiley-Blackwell, 2080-2093

Holder R. D. (2014) Ultrasound determination of fetal sex. In: Dascanio J. and McCue P. (eds.), Equine Reproductive Procedures 1 st Edition, John Wiley and Sons, 195-200

Hubbell J. A. E. (2011) Sedation and anesthesia of the pregnant mare. In: McKinnon A. O., Squires E. L., Vaala W. E., Varner D. D. (eds.), Equine Reproduction 2nd Edition, Ames:Wiley-Blackwell, 55-60

Livini M. (2010) Determination of fetal gender by transrectal ultrasound examination: Field's experience. Proceedings of the Annual Convention of the AAEP, 323-327

Mari G., Castagnetti C., Beluzzio S. (2002) Equine fetal sex determination using a single ultrasonic examination under farm conditions. Theriogenology 58, 1237-1243

Merkt H., De Andrade Moura J. C., Jöchle W. (1999) Gender determination in equine fetuses between 50 and 90 days of gestation. J. Equine Vet. Sci. 19, 90-94
Reef B., Vaala E., Worth T., Hammett B. (1995) Ultrasonographic evaluation of the fetus and intrauterine environment in healthy mares during late gestation. Vet. Radiol. Ultrasound 36, 533-54 1

Renaudin C. D., Gillis C. L., Tarantal A. F. (1997) Transabdominal combined with transrectal ultrasonographic determination of equine fetal gender during midgestation. Proceedings of the Annual Convention of the AAEP 43, 251-255

Resende H. L., Carmo M. T., Ramires Neto C., Alvarenga M. A. (2014) Determination of equine fetal sex by Doppler ultrasonography of the gonads. Equine Vet. J. 46, 756-758

Schönbom H., Kassens A., Hopster-Iversen C., Klewitz J, Piechotta M., Martinsson G., Kißler A., Burger D., Sieme H. (2014) Influence of transrectal and transabdominal ultrasound examination on salivary cortisol, heart rate, and heart rate variability in mares. Theriogenology, doi.org/10.1016/i.theriogenology.2014.11.010

Erweiterte Zusammenfassung

\section{Geschlechtsbestimmung am Pferdefetus in der frühen und fortgeschrittenen Trächtigkeit}

Wirtschaftliche Abwägungen nehmen auch in der modernen Pferdezucht immer mehr an Bedeutung zu. Bei dem Verkauf von Zuchtstuten muss sehr genau überlegt werden zu welchen Konditionen man sich von welchen Pferden trennt. Bei tragenden Stuten kann das Wissen um das Geschlecht des zu erwartenden Fohlens für solch schwerwiegende züchterische Entscheidungen eine wertvolle Hilfestellung sein und den Verkaufswert der Stute beeinflussen.

Die Geschlechtsbestimmung am Pferdefetus in der frühen und fortgeschrittenen Trächtigkeit kann zu drei unterschiedlichen Zeitpunkten durchgeführt werden. Der frühest mögliche Zeitpunkt liegt zwischen dem 54. und 84. Trächtigkeitstag. Durch eine transrektale Ultraschalluntersuchung kann hier anhand des Genitalhöckers das Geschlecht des Fetus vorausgesagt werden. Zuerst muss die Längsachse des Fetus aufgefunden werden, als Orientierungspunkte dienen kranial der knöcherne Schädel und das schlagende Herz, kaudal der typisch bohnenförmige Magen, dorsal die knöcherne Wirbelsäule und ventral die Nabelschnur. Der Genitalhöcker ist der Vorläufer von Penis bzw. Klitoris. Er kann ab dem 52. Trächtigkeitstag zwischen Schweifansatz und Nabelschnur aufgefunden werden, aber erst ab dem 54. Tag nimmt er eine geschlechtsspezifische Lage ein. Bei weiblichen Tieren wandert er nach kaudal, Richtung Schweifansatz, bei männlichen Tieren nach kranial, Richtung Nabelschnur. Durch das Schallen des Höckers in verschiedenen Ebenen (frontal, schräg, im Querschnitt) kann die Lokalisation genau festgelegt und das Geschlecht bestimmt werden. Bei männlichen Feten lässt sich der Genitaltuberkel in mehreren Ebenen als hyperechogenes Signal ventro-median, kaudal der Nabelschnur darstellen. Bei weiblichen Feten ist eine Ebene vertikal zu den fetalen Wirbeln zur Darstellung des Perinealbereichs zu wählen. Drei hyperechogene Strukturen sind dann darstellbar - der Schweif mit dem beide Unterschenkel ein Dreieck formen und der weibliche Genitaltuberkel liegt unmittelbar unter dem Schweifansatz. Die besten Ergebnisse werden bei dieser Methode zwischen dem 59. und 68. Tag erzielt. Nach dem 80. Trächtigkeitstag sinkt die Gebärmutter, aufgrund der Zunahme der Fruchtwässer, über das knöcherne Becken hinaus, tief in die Bauchhöhle. Der Genitalhöcker ist nunmehr kaum mit dem Schallkopf erreichbar. Diese Art der 
Geschlechtsbestimmung ist sehr speziell, sie erfordert eine gute Ausstattung (Ultraschallgerät mit Frequenzbereich von 5-7,5 MHz mit Linearschallkopf, Untersuchungsstand, abgedunkelter Raum, Datenspeicherung), viel Erfahrung und Geduld des Untersuchers und kooperative Patienten. Von einer Sedierung der Stute sollte wenn möglich abgesehen werden. Dies könnte den Fetus beeinflussen und ein tieferes Absinken des Uterus in das Abdomen wird begünstigt. Das wiederum führt zu einem größeren Abstand zwischen Schallkopf und Fetus und die Untersuchung wird zusätzlich erschwert. Eine medikamentelle Darmrelaxation ist - wenn nötig - hilfreich. Die kurze Zeitspanne in der die transrektale Geschlechtsbestimmung in der frühen Gravidität aussagekräftige Befunde liefert und das Erheben von nur einem Parameter am Fetus ist als nachteilig zu bewerten.

Zwischen dem 90. und 140. Tag kann die Geschlechtsbestimmung anhand der primären Geschlechtsorgane und anhand der fetalen Gonaden durchgeführt werden. Solange sich der Fetus in Hinterendlage oder auch in Querlage befindet, kann der hintere Bereich der Frucht via transrektaler Sonographie erreicht werden. Nach dem 140. Tag ist ein Erreichen des hinteren Viertels des Fetus mit der Ultraschallsonde nahezu unmöglich. Auch hier sollte zuerst die Position des Fetus bestimmt werden, damit dann gezielt die Geschlechtsmerkmale aufgesucht werden können. Bei weiblichen Feten dienen das Euter mit Zitzen, die Vulva, die Klitoris und die Gonaden als Erkennungsmerkmale. Bei männlichen Feten erfolgt die Geschlechtsbestimmung anhand von Penis, Skrotum, Urethra und Gonaden. In ihrer ovalen Form und ihrer Lage ventrokaudal der Nieren gleichen sich die Gonaden in beiderlei Geschlecht. Sie weisen jedoch bei der Untersuchung im B-Mode eine unterschiedliche Echotextur auf und zeigen bei der Sonographie mit Doppler ein unterschiedliches Durchblutungsmuster. Weibliche Gonaden weisen im BMode eine typische Zweizonigkeit auf, diese spiegelt die unterschiedlichen Gewebestrukturen von Cortex (Gefäßschicht, außen) und Medullar (Markschicht, innen) wider (vergl. transabdominale Untersuchung Abb.1 B), dementsprechend ist ein ringförmiges Signal bei der Dopplersonographie zu beobachten (vergl. transabdominale Untersuchung Abb.1 D). Männliche Gonaden weisen im B-Mode homogene Echogenität, ähnlich der des Lebergewebes auf mit einer zentralen hyperechogenen Linie entlang der Longitudinalachse (vergl. transabdominale Untersuchung Abb. 1. A). Diese entspricht der Lokalisation des Rete Testis. Da sich in diesem Bereich des Hodens auch vermehrt Blutgefäße befinden, zeigt sich hier beim Doppler ebenfalls ein intensives Signal (vergl. transabdominale Untersuchung Abb. 1 C). Häufig wird auch ein Dopplersignal an der lateralen Kontur des Hodens gesehen, hierbei handelt es sich um die Darstellung des durchbluteten Plexus pampiniformis. Dieser ist jedoch nicht bei jeder Untersuchung darstellbar.

Ab dem 150. Trächtigkeitstag ist die transabdominale Sonographie das Mittel der Wahl zur Geschlechtsbestimmung am Fetus, da sich dieser jetzt in der Regel in Vorderendlage befindet und seine Hinterhand bei einer transrektalen Untersuchung kaum erreichbar ist. Beurteilt werden ebenfalls äußere Geschlechtsmerkmale und Gonaden. Auch zu einem früheren Zeitpunkt (ab 90. Tag) bietet sich diese Form der Untersuchung an, da sie weniger invasiv ist, keine Gefahr der Perforation der Darmwand birgt, von den Stuten meist problem- los toleriert wird und bei den Besitzern auf große Akzeptanz stößt. Bei unruhigen Pferden kann problemlos die Position des Schallkopfes auf dem Abdomen immer wieder neu angepasst werden um den Fetus aufzufinden. In Kauf genommen werden muss hierbei jedoch die längere Vorbereitungszeit. Ein Ultraschallgerät, das in einem Frequenzbereich von $2-6 \mathrm{MHz}$ arbeitet und eine Eindringtiefe von bis zu $25 \mathrm{~cm}$ erreichen kann und ein konvexer Schallkopf sind erforderlich. Das Abdomen wird vom Euter bis zum Xyphoid mit einem alkoholischen Hautdesinfektionsmittel benetzt, der Fetus wird im Abdomen der Stute lokalisiert und Orientierungspunkte werden gesetzt (fetales Herz, Magen, Wirbelsäule, Nabelschnur). Je weiter die Trächtigkeit fortgeschritten ist, desto weiter kranial kann die Hinterhandpartie des Fetus liegen. Nach dem 8. Trächtigkeitsmonat befindet sich diese meist im kranialen Drittel des Abdomens der Stute, nahe dem Brustbein. Mit fortschreitender Trächtigkeit gestaltet sich die Geschlechtsbestimmung zunehmend schwieriger, da der Fetus an Größe zunimmt, was wiederum Schallschatten verursacht. Besonders das Auffinden der äußeren Geschlechtsmerkmale gestaltet sich nach dem 200. Tag schwierig. Mindestens drei der beschriebenen Merkmale sollten erhoben werden, bevor eine Aussage über das Geschlecht des Fetus getroffen wird. Bei Stuten: Euter mit Zitzen, Vulva, Klitoris, Gonaden (im B-Mode typische Zweizonigkeit, mittels Doppler ein kreisförmiges Signal; s. Abb. 1 B u. D). Bei Hengsten: Penis, Skrotum, Urethra, Gonaden (im B-Mode homogen mit zentraler Aufhellung, mittels Doppler zentrales Signal, ggf. zusätzliches Signal an lateraler Kontur; s. Abb. 1 A u. C).

Die Sicherheit einer richtigen Voraussage mit den o.a. Methoden steigt mit zunehmender Erfahrung des Untersuchers; eine 100-prozentige Sicherheit wird kaum erreicht werden können. Ist sich der Untersucher unsicher, sollte die Untersuchung zu einem späteren Zeitpunkt wiederholt werden. Zwar ist bei der transabdominalen Untersuchung der Abstand zwischen Schallkopf und Fetus größer, als bei der transrektalen Untersuchung, was bewirkt, dass das Ultraschallbild etwas unschärfer sein kann. Dennoch ist die transabdominale Vorgehensweise, sofern Ausrüstung und Erfahrung vorhanden, vorzuziehen. Das Verletzungsrisiko für die Stute und den seitlich stehenden Untersucher ist geringer. Bei nicht-laktierenden tragenden Stuten ist die transabdominale Vorgehensweise mit weniger Stress verbunden. Je mehr Erfahrungen der Untersucher hat, desto schneller kann der Fetus dargestellt, seine Lage festgestellt, die äußeren Geschlechtsmerkmale und Gonaden aufgefunden und das Geschlecht bestimmt werden. Außerdem bietet die transabdominale Vorgehensweise sehr gute Möglichkeiten für eine Trächtigkeitskontrolle bei fortgeschrittener Trächtigkeit und ermöglicht die Evaluierung bedeutsamer Vitalparameter an der Frucht wie Herzschlag/freqenz, Aortendurchmesser, Größe, fetale Bewegungen, Menge, Echogenität und Partikelgehalt der Fruchtwässer sowie die Beurteilung der feto-plazentaren Verbindung (CTUP (Combined Thickness of Uterus and Placenta)). Auch bei kleinen Pferderassen und Ponys, bei denen eine transrektale Untersuchung nicht möglich ist, bietet die transabdominale Vorgehensweise eine praktikable Möglichkeit zur Feststellung der Trächtigkeit und Beurteilung der Vitalität des Fetus.

Schlüsselwörter: Stute / fetale Geschlechtsbestimmung / fetus / transrektale Sonographie / transabdominale Sonographie / Reproduktion 